\title{
Authority Control
}

Compiled by Anna Appleman

Billey, Amber. “Just Because We Can, Doesn’t Mean We Should: An Argument for Simplicity and Data Privacy With Name Authority Work in the Linked Data Environment.” Journal of Library Metadata 19, no. 1/2 (January 2019): 1-17.

Cannan, Judith P., Paul Frank, and Les Hawkins. "LC/NACO Authority File in the Library of Congress BIBFRAME Pilots.” Journal of Library Metadata 19, no. 1/2 (January 2019): 39-51.

Craft, Anna R. "Local Name Authorities and Linked Data: The Landscape.” Serials Review 45, no. 1-2 (January 2019): 61-65.

Downey, Moira. “Assessing Author Identifiers: Preparing for a Linked Data Approach to Name Authority Control in an Institutional Repository Context.” Journal of Library Metadata 19, no. 1/2 (January 2019): 117-36.

Jin, Qiang, and Deren Kudeki. “Identity and Access Management for Libraries.” Technical Services Quarterly 36, no. 1 (January 2019): 44-60.

Mugridge, Rebecca L., Rebecca Nous, Nancy Poehlmann, and Wendy West. "Benchmarking Vended Authority Control Practices in ARL Libraries.” Technical Services Quarterly 35, no. 4 (October 2018): 323-37.

Piscitelli, Felicia A. "When Does the Forename End and the Surname Begin? Saints' Names as Compound Forenames in Spanish.” Cataloging \& Classification Quarterly 57, no. 4 (May 2019): 187-96. 